\title{
Characterizing Bacterial Consortia from an Anaerobic Digester Treating Organic Waste for Biogas Production
}

\author{
Rabia Liaquat $^{1}$, Asif Jamal ${ }^{1}$, Isfahan Tauseef ${ }^{2}$, Zahid Qureshi ${ }^{3}$, Uzma Farooq4, \\ Muhammad Imran ${ }^{1}$, Muhammad Ishtiaq Ali ${ }^{1 *}$ \\ ${ }^{1}$ Department of Microbiology, Quaid-i-Azam University, Islamabad, Pakistan \\ ${ }^{2}$ Department of Microbiology, Hazara University KPK, Pakistan \\ ${ }^{3}$ Department of Chemistry, Govt. College University Lahore, Pakistan \\ ${ }^{4}$ Department of Plant Sciences, Quaid-i-Azam University, Islamabad, Pakistan
}

Received: 6 August 2015

Accepted: 8 September 2015

\begin{abstract}
Microorganisms play a significant role in anaerobic digestion of organic matter in order to add up the chemical substances in the ongoing biochemical process. The microbes are responsible for the efficient breakdown of complex organic molecules through a series of biochemical reactions for methane production. In the present study inoculums were collected from three different sources - a sewage sludge wastewater treatment plant (SS), cow dung (CD), and an anaerobic reactor treating inoculum from organic matter (IOM) - to evaluate their potential for anaerobic digestion of agricultural residues (AR) and fruit vegetable waste $(\mathrm{FVW})$ at mesophilic temperature $\left(35^{\circ} \mathrm{C}\right)$. The higher biogas production of $507 \mathrm{l} / \mathrm{gVS}$ was achieved for a mixture of inoculums $(\mathrm{SS}+\mathrm{CD}+\mathrm{IOM})$ in reactor $4(\mathrm{R} 4)$, and biogas characterization by gas chromatography (GC) reveals $67.7 \%$ of the methane content. The morphological, biochemical, and molecular techniques were used to identify the microbial flora present in the high-yield reactor. The abundance of Bacillus, clostridium, and Enterobacter spp were observed along with Methanomicrobia and Methanosarcina. To get a high methane yield from organic waste it is necessary to maintain the equilibrium and availability of efficient microbial communities like firmicutous, hydrogenotrophic, and acitoclatic methanogens.
\end{abstract}

Keywords: methanogens, organic matter, isolation, molecular identification

\section{Introduction}

Energy plays a significant role in the development of any country [1]. To achieve this indispensable need, combustion of fossil fuels increases, but they are nonrenewable and terminable resources [2]. The burning of fossil fuels (for instance natural gas, coal, and oil) releases greenhouse gases that cause global warming [3]. To fulfill the requirements of billions of people, due to environmental issues and continuous exhaustion of fossil fuels it is necessary to explore eco-friendly, renewable, and inexpensive energy sources [4]. Among all renewable energy sources such as solar, wind, and various hydro and

*e-mail: ishi_ali@hotmail.com 
thermal resources, biogas is a distinctive energy resource as it is eco-friendly, easy to handle, yields bio-fertilizer, and has the capability to be employed for power, heating, and vehicle fuels.

Biogas is produced through the process of anaerobic digestion by the conversion of organic fraction of decomposable waste [5]. It is a mixture of different gases like methane (60-65\%) and carbon dioxide with trace amounts of other gases [6]. Organic content of the different wastes (such as agricultural and kitchen waste, municipal solid waste, and manure) is used as a substrate for energy recovery in a biogas production process [7]. Beside the sustainability of the process, it reduces the odor, sludge volume, and pathogens; furthermore, the digestate can be used as a fertilizer [8].

Anaerobic digestion is carried out by a diverse group of microbes through metabolic reactions occurring in series, such as hydrolysis, acidogenisis, acetogenisis, and methanogenesis [9]. A wide range of organic waste can be decomposed through anaerobic digestion, including industrial, domestic, agricultural, municipal, dairy, and food waste [10]. When optimizing a substrate/inoculum ratio, a source of inoculum is a key parameter that can be used for the treatment of waste sludge, even by naturally isolated microorganisms or as a developed microbial consortium [11]. Most of the organic waste is digested by the heterotrophic organisms [12]. A microbial consortium is involved in the anaerobic digestion of organic waste, as it is unusual that waste digestion relies on a single microbial strain [13]. Under anaerobic conditions Clostridium species are the common degraders [14]. Variations of organisms such as Actinomyces, Thermomonospora, Ralstonia, and Shewanella are responsible for the digestion of organic waste into volatile fatty acids, while Methanobacterium/ Methanobrevibacter and Methanosarcina are involved in methane production [15]. Higher concentrations of organic acids (butyric acid, acetic acid) hinder the growth of microorganisms in a bioreactor, though, therefore decreasing energy-rich compound production [16].

Fruit and vegetable waste (FVW) has potential for biogas generation due to its biodegradable nature and higher moisture content of about $75-95 \%$. They have an organic content of about $75 \%$ of sugar and hemicelluloses, and $9 \%$ and $5 \%$ of cellulose and lignin, respectively. Better methane production is reported by using kitchen waste as a substrate during anaerobic digestion, as opposed to other wastes like municipal waste [17]. A high percentage of carbohydrates are reported in kitchen waste, which increases the production of volatile fatty acids, thus enhancing the acidification process and leading to the low methanogenic activity of the digester [18].

Co-digestion is considered an economically feasible process for managing different organic substrates and enhancing biogas production in an anaerobic digestor [19]. Different organic waste like sewage sludge, animal manure, and agricultural waste can be co-digested along with fruit and vegetable waste (FVW) anaerobically for biogas production [17]. Co-digestion of various waste streams promotes the methanogenic activity due to supplementary nutrients from the organic substrate [20].

The Pakistani population has been increasing rapidly, causing huge gaps in demand and supply of energy [21]. On the other hand, the rising demand of fossil fuels, a major source of energy, not only is depleted daily but also involves huge capital investment [22]. In Pakistan solid waste is generated in the range of 0.283 to $0.612 \mathrm{~kg} / \mathrm{capita} /$ day. The solid waste is dumped off on land, which causes health hazards through air and water pollution. Anaerobic digestion of waste and the generation of biogas/bioenergy is the economical and environmental friendly approach to transform waste into opportunity. Although anaerobic digestion has been practiced for decades, recent interest typically focused on a cost-effective recovery of energy from agricultural, household/kitchen, and industrial wastes.

\section{Material and Methods}

\section{Inoculum Source and Substrate Collection}

The sewage sludge (SS) inoculum was collected from wastewater treatment plant H-9 Islamabad, cow dung (CD) from a local farm house, and the inoculum from a laboratory continuously stirred tank reactor (CSTR) treating organic matter (IOM) and operating at $35^{\circ} \mathrm{C}$. The agricultural waste was collected from the Mal-Pur agricultural land (Village near QAU) and fruit-vegetable waste (FVW) from the Islamabad Market. Before use the substrate and inoculums were stored at $4^{\circ} \mathrm{C}$ in sealed containers.

\section{Experiment Setup}

Stainless steel batch reactors containing the mixture of AR and FVW with working volume of 5L were used to evaluate biogas production. The reactor was inoculated with individual and mixed bacterial cultures to evaluate their performance (Table 1). The $\mathrm{pH}$ in the reactor was maintained at 7 with a $0.8 \mathrm{~N} \mathrm{NaOH}$ solution. The reactor was operated in mesophilic conditions $\left(35^{\circ} \mathrm{C}\right)$. The reactor contains a stirring rod, which manually operated two times daily for mixing.

Table 1. The substrate and inoculum setup in each reactor.

\begin{tabular}{|c|c|c|}
\hline Reactor \# & Substrate (1:1) & Inoculum \\
\hline R1 & AR+FVW & SS \\
\hline R2 & AR+FVW & CD \\
\hline R3 & AR+FVW & IOM \\
\hline R4 & AR+FVW & SS+CD+IOM \\
\hline
\end{tabular}

$\mathrm{AR}=$ agricultural residues, $\mathrm{FVW}=$ fruit-vegetable waste, $\mathrm{SS}=$ sewage sludge, $\mathrm{CD}=$ cow dung, $\mathrm{IOM}=$ inoculum from organic matter. 


\section{Analytical Methods}

The influent and effluent samples were collected to analyze physiochemical parameters, total solids (TS), volatile solids (VS), moisture content, and $\mathrm{pH}$. All the physiochemical analyses were performed according to the standard methods [23].

\section{Gas Chromatography (GC)}

Biogas production volume was determined by the water displacement method. Biogas composition was determined by Agilent gas chromatography (GC-6820, Agilent in USA). A thermal conductivity detector (TCD), an HP PLOT Q column, and helium gas as a carrier gas in GC were applied for biogas measurement. The temperature of the oven, injector, and detector were of 100,120 , and $120^{\circ} \mathrm{C}$, respectively. For GC calibration the controls of $\mathrm{CH}_{4}$ and $\mathrm{CO}_{2}$ were used [24]. Two-way ANOVA of biogas production, methane content, and VS reduction percentage was performed through Graph prism software (v. 8) while using four different inoculums.

\section{Isolation of Anaerobic Bacteria}

For the initial growth and screening of bacteria collected from the batch reactor, we used nutrient broth (OXOID), nutrient agar (OXOID), and thio-glycolyte broth (OXOID). The composition of basal medium for the selective enrichment and growth of anaerobic and methnaogenic bacteria was: $\mathrm{KH}_{2} \mathrm{PO}_{4}(0.75 \mathrm{~g})$, $\mathrm{k}_{2} \mathrm{HPO}_{4} \cdot 3 \mathrm{H}_{2} \mathrm{O}(1.45 \mathrm{~g}), \mathrm{NH}_{4} \mathrm{Cl}(0.9 \mathrm{~g}), \mathrm{MgCl}_{2} \cdot \mathrm{H}_{2} \mathrm{O}(0.2 \mathrm{~g})$, $\mathrm{Na}_{2} \mathrm{~S}_{9} 9 \mathrm{H}_{2} \mathrm{O}(0.5 \mathrm{~g})$, trace mineral solution $(9 \mathrm{ml})$, vitamin solution $(5 \mathrm{ml})$, resazurin solution ( $1 \mathrm{ml}$ of $0.2 \%$ ), distilled water $(1,000 \mathrm{ml})$, and $2 \%$ Agar (OXOID). The culturing was performed in an anaerobic chamber and plates were placed in an anaerobic jar (OXOID) to ensure anaerobic conditions. The plates were incubated at $35^{\circ} \mathrm{C}$ for $24-48$ hrs.

\section{Microbial Analysis}

The isolated strains from three different sources were phenotypically characterized by growth features on growth media, microscopic examination, motility test, and gram staining. Biochemical tests were performed using an API kit (API-20). Methanogenic bacteria were separated from non-methanogenic bacteria on the basis of their shape, gram reaction, motility, growth conditions, catalase test, $\mathrm{pH}$, and temperature requirements.

\section{Molecular Characterization}

The sample from the anaerobic digester (AD) performing with mixed inoculum was collected for DNA extraction according to the protocol provided by the MOBIO Powersoil DNA isolation kit. The DNA of isolated bacterial strain was extracted by the CTAB/Chloroform-
Table 2. Properties of agricultural waste (AW) and fruit vegetable waste (FVW).

\begin{tabular}{|c|c|c|}
\hline Parameters & AW & FVW \\
\hline TS (wt \%) & 87 & 21.5 \\
\hline VS (wt \%) & 82 & 18.7 \\
\hline Moisture Content (\%) & ND & 85 \\
\hline $\mathrm{pH}$ & ND & 5.4 \\
\hline
\end{tabular}

Isoamyl Alcohol DNA Extraction Protocol [25]. The Nanodrop Spectrophotometer was used to quantify the extracted DNA and stored at $-20^{\circ} \mathrm{C}$. The polymerase chain reaction (PCR) was carried out using universal 16s rRNA primers (518F and 800R). PCR products were sent to MACROGEN Korea for sequencing. The consensus sequences were analyzed with BLAST as per the National Center for Biotechnology Information (NCBI). Based on sequence analysis, phylogenetic trees were constructed using MEGA 6.0 and CLUSTAL. W. Package by the neighbor-joining method.

\section{Result and Discussion}

\section{Characteristics of the Substrates}

The physiochemical characterization of agricultural residues and fruit-vegetable waste was carried out and is presented in Table 2.

\section{Reactor Performance}

Biogas production, methane content, and VS reduction of three different inoculums and their mixture on the day 20 is shown in Table 3. It indicates that biogas production is about $254,314,432$, and $507 \mathrm{~L}$ in R1, R2, R3, and R4, respectively. Methane content (68.7\%) and VS reduction (71\%) were the highest in R4.

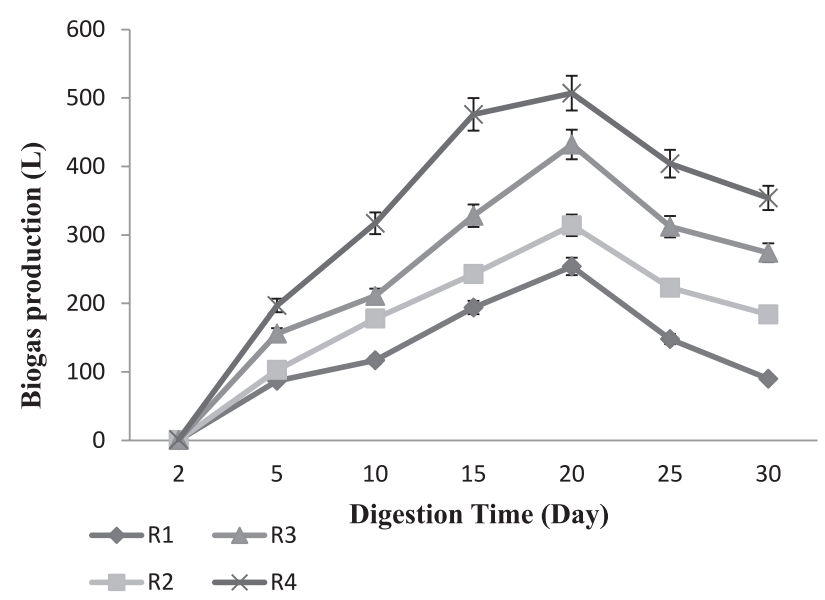

Fig. 1. Biogas production in the rectors (R1-4). 
Table 3. Biogas production, methane content, and VS reduction in reactors (R1-4) at day 20.

\begin{tabular}{|c|c|c|c|}
\hline Reactor \# & $\begin{array}{c}\text { Biogas } \\
\text { Production } \\
(1 / \mathrm{gVS})\end{array}$ & $\begin{array}{c}\text { Methane } \\
\text { Content } \\
(\%)\end{array}$ & $\begin{array}{c}\text { VS Reduction } \\
(\%)\end{array}$ \\
\hline R1 & 254 & 54.8 & 58 \\
\hline R2 & 314 & 63.3 & 60 \\
\hline R3 & 432 & 61.4 & 68 \\
\hline R4 & 507 & 67.7 & 73 \\
\hline
\end{tabular}

$\mathrm{R}=$ Reactor

\section{Biogas Production in Four Different Reactors}

Biogas production in different batch reactors (R1-R4) on days $2,5,10,15,20,25$, and 30 was estimated (Fig. 1), indicating that on day 20 biogas production was highest in each reactor. Initially, biogas production was relatively slower due to limited microbial growth in the reactor. A rapid increase in biogas production was observed after day 5 . With the passage of reaction time, a gradual increase in biogas was observed; however, after the day 20 , the rate of product formation was markedly decreased. The highest biogas production was observed in R4 (5,071/g VS) (Table 3 and Fig. 1). The maximum level of biogas production in R4 was possibly due to acidogenis and methanogenisis, indicating a promising role of mixed bacterial cultures. It has been previously reported that the addition of active inoculum containing mixed bacterial cultures in the bioreactor proved to be more promising for biogas production at $35^{\circ} \mathrm{C}$ and $55^{\circ} \mathrm{C}[26]$.

\section{Methane Content in Four Different Reactors}

Fig. 2 and Table 3 show the highest methane contents in reactors R4 (67.7\%) and R2 (63.3\%). Even biogas production was higher in R3 than R2, which was

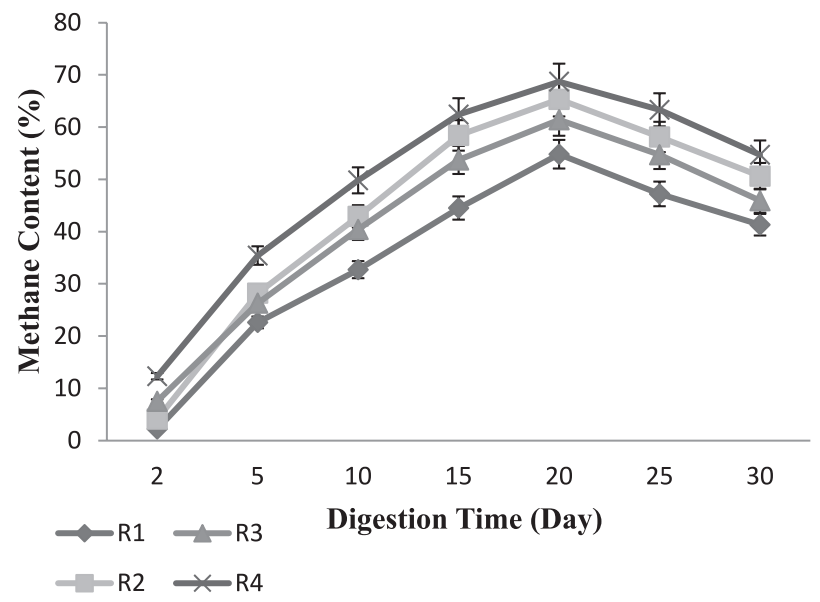

Fig. 2. Methane content in the reactors (R1-4).

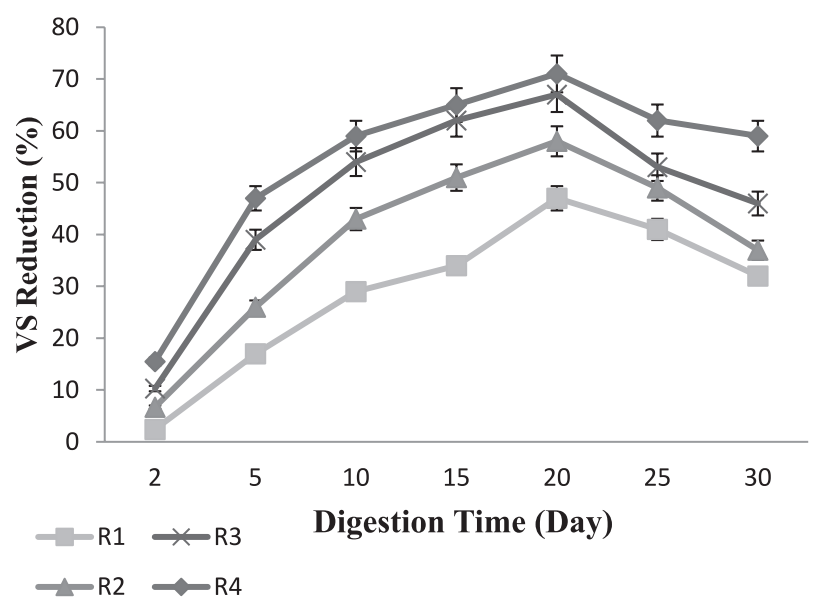

Fig. 3. VS reduction in the reactors (R1-4).

inoculated with strains isolated from cow dung (CD). Like biogas production, higher methane content was achieved on day 20.

Another study reported the methanogenic and nonmethanogenic community, consortium with more methanogens gave a $76 \%$ methane and other rectors containing facultative anaerobes resulted in low methane content [27]. Anaerobic digestion of organic waste using different bacterial inoculum, the bacterial consortia with high abundance of methanogenic community

a)

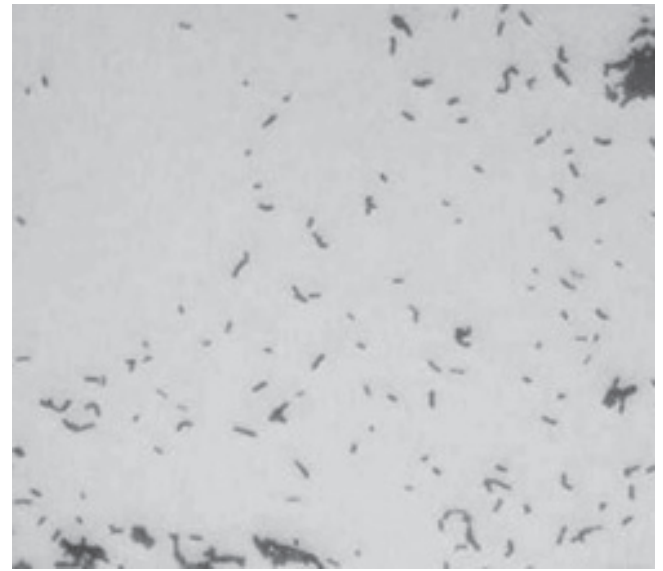

b)

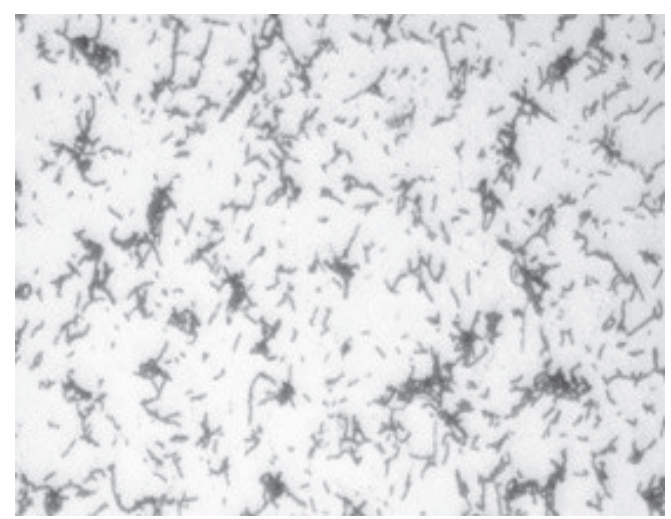

Fig. 4. a) Gram staining Enterobacter sp. RL-1.; b) Clostridium perfringens RAS-4. 
gave a $79.45 \%$ methane content representing the efficient microbial consortia degrading organic content [28].

\section{VS Reduction in Four Different Reactors}

The lowest biogas production $(254 \mathrm{~L})$ and VS reduction (of 47\%) was recorded in R1 (Fig. 3, Table 3). As biogas production started to decrease after day 20, similarly the utilization of VS was reduced in each reactor. The highest digestion of solids $(73 \%)$ in R4 may be due to the consortium of highly active methanogens. As previous studies have reported, the anaerobic digestion of food and green waste resulted in $80.8 \%$ VS destruction [29].

\section{Statistical Analysis}

Two-way ANOVA of Biogas production, methane content, and VS reduction was estimated by using graph prism software (v. 8). Both column factor and row factor P-values were $<0.0001$, presenting significant differences among the three inoculums and their mixtures.

\section{Isolation and Morphological Characterization of Anaerobes}

In the present study the bacteria isolated from the digester treating the AR and FVW by the mixed inoculum from three different sources were used in the digestion of organic waste for biogas production. The isolated bacterial strains were identified morphologically on the basis of gram staining (Figs 4a-b), shape, motility, and their behavior in thioglycolyte broth. The morphological and biochemical characteristics of isolated strains are presented in Tables 4 and 5, respectively.

\section{Molecular Characterization of Microbial Community}

\section{Molecular Identification}

The genomic sequences of the microbial isolates were showing similarities to different phyla, like Firmicutes and Archea. Firmicutes are the syntrophic and fermenters bacteria that digest the VFAs. Their abundance in a digester is dominant because of the availability of VFAs. The phylum fermicutus majorly have two classes: Clostrdia (13\%) and Bacilli (76\%) [30]. The clostridium

Table 4. Morphology of strains and thioglycolate test results.

\begin{tabular}{|c|c|c|c|c|c|}
\hline S\# & Morphology of isolates & $\begin{array}{c}\text { Gram } \\
\text { staining }\end{array}$ & Shape & Motility & $\begin{array}{c}\text { Thioglycolate } \\
\text { Broth test }\end{array}$ \\
\hline RL-1 & Flat, circular and entire margin & - & Rod & Motile & Facultative anaerobe \\
\hline RAS-1 & Raised circular medium size colonies & + & Rod & Motile & Obligate anaerobe \\
\hline RAS-2 & yellow, circular, convex colonies & - & Cocci & Non Motile & Strict anaerobe anaerobe \\
\hline RAS-3 & Ovoid in pairs & + & Coccus & Motile & Strict anaerobe anaerobe \\
\hline RAS-4 & Creamy large, white intact colonies & + & Rod & Motile & Obligate anaerobe \\
\hline RAS-5 & Circular, white intact colonies & + & Cocci & Motile & Facultative anaerobe \\
\hline RAS-6 & Raised, granular small colonies & + & Rod & Motile & Obligate anaerobe \\
\hline RAS-7 & Creamy, large, intact colonies & - & Rod & Motile & Facultative anaerobe \\
\hline
\end{tabular}

Table 5. Biochemical characterization of isolated strains.

\begin{tabular}{|c|c|c|c|c|c|c|c|}
\hline Test & Indole & MR & VP & Citrate & Catalase & Oxidase & Identified strains \\
\hline RL-1 & - & - & + & + & + & - & Enterobacter sp \\
\hline RAS-1 & - & - & + & + & + & + & Bacillus cereus \\
\hline RAS-2 & + & + & + & + & - & + & Methanosarcina \\
\hline RAS-3 & - & - & + & + & + & + & Bacillus cereus \\
\hline RAS-4 & - & - & - & + & - & - & Colustridium perferingens \\
\hline RAS-5 & - & - & - & + & - & - & Colustridium spp \\
\hline RAS-6 & + & - & + & + & - & + & Colustridium sartagoforme \\
\hline RAS-7 & - & + & + & + & - & - & Enterococcus faecium \\
\hline
\end{tabular}

$\mathrm{MR}=$ methyl red, $\mathrm{VP}=$ voges proskauer 
spp are are responsible for consumption of aminoacids and production of acetate, ammonia, and butyrate [31]. The accession number of cultured organisms were: Enterobacter spp. RL-1 (KJ961633) Bacillus subtilis RAS-1(KP799011), Clostridium perfringens. RL-2 (KP064191), Bacillus sp. RL-3, RL-7, RL-11, RL-12, Rl-13 (KP064192, KP064194, KP064198, KP064199, KP064200), Enterobacter sp. RL-6 and RL-10 (KP064193, KP064197), Clostridium sp. RL-8 (KP 064195),
Escherichia sp.RL-9 (KP064196) and Methanomicrobia archaeon, RL-18 (KP064201). The Phylogenetic tree of RAS-1, RAS-4, and RL-1 are shown in Figs 5, 6, and 7. Diversified microbial communities responsible for anaerobic digestion of organic matter have been reported from different ecological sources. It has been suggested that mostly the heterotrophic community has a significant role in decomposition of organic wastes [32].

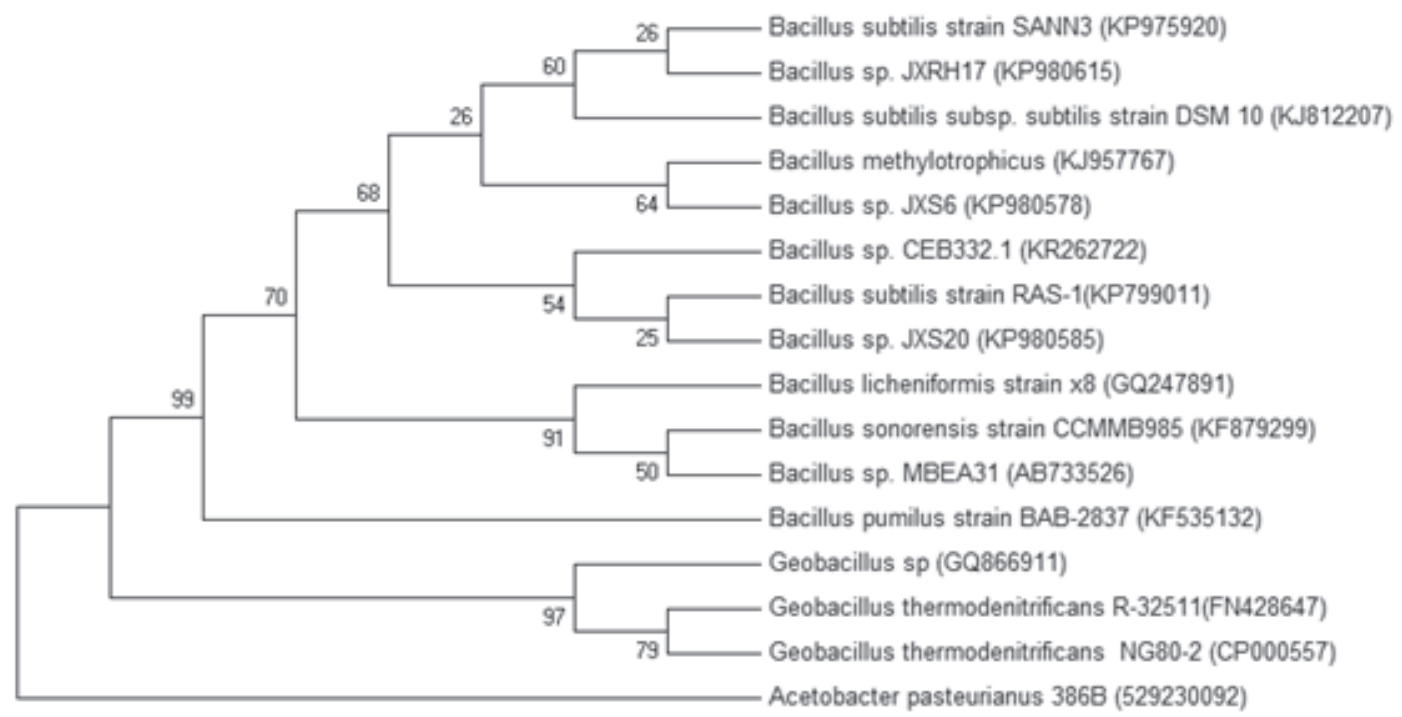

Fig. 5. Phylogenetic tree of Bacillus subtilis RAS-1.

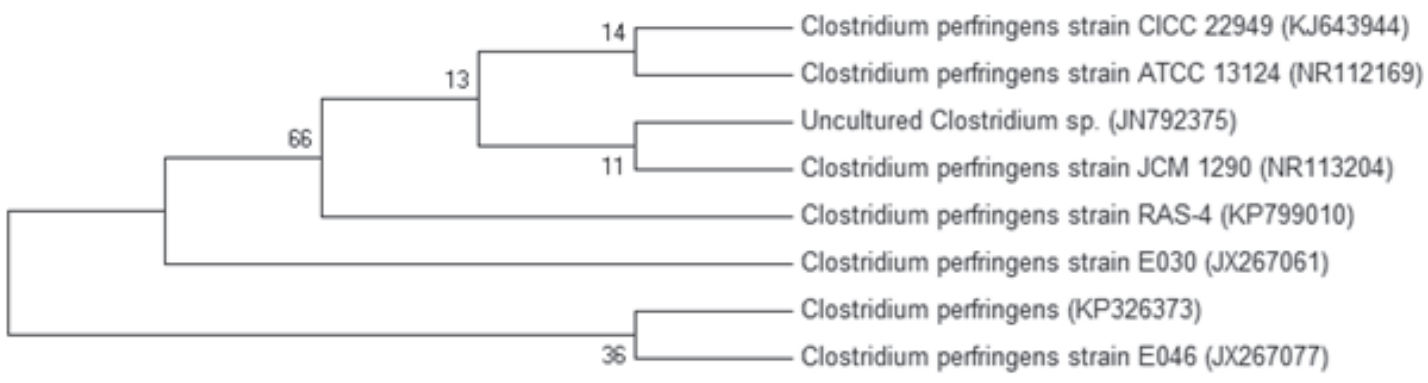

Fig. 6. Phylogenetic tree of Clostridium perfringes RAS-4.

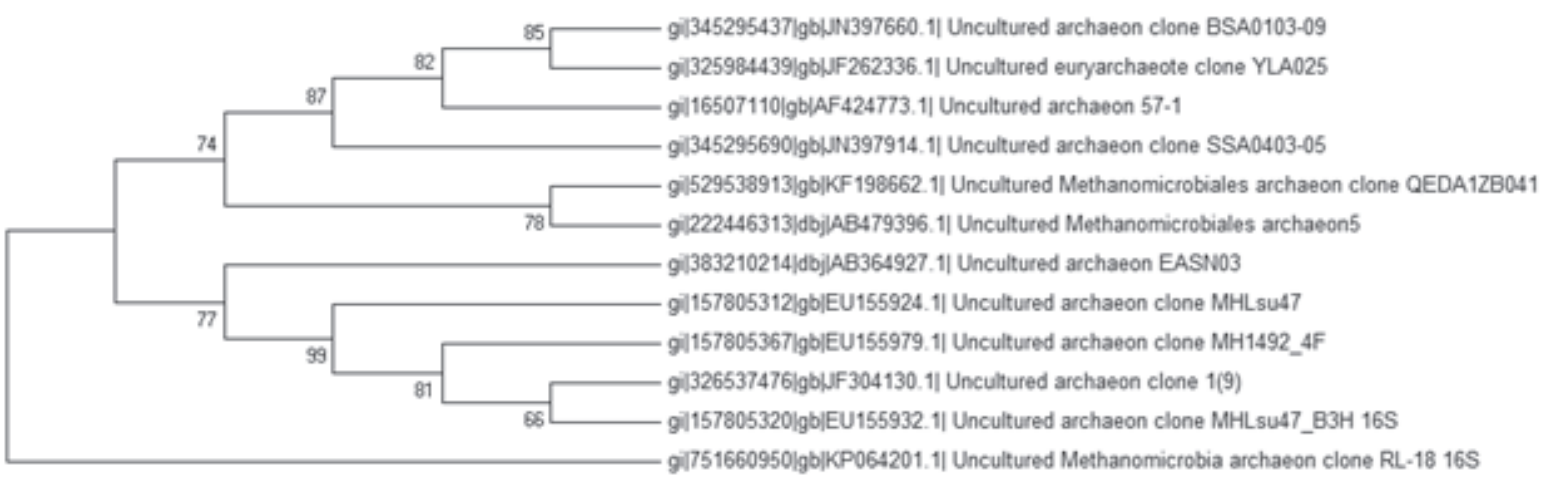

Fig. 7. The Phylogenetic tree of Methanomicrobia $R L-18$ 
Under anaerobic conditions Clostridium species are abundant degraders [33]. For a biochemical process it is very unlikely that the process depends on a single microbial strain, for absolute conversion of substrate, a consortium of the microbial community is accountable. Previous studies have indicated that the presence of methanogens like Methanobacterium curvum Methanosaeta, Methanosarcina, and Methanobrevibacter/ Methanobacterium are indicators of methane production in an anaerobic digestor [34]. Trzcinski et al. reported that an increase in the abundance of hydrogenotrophic methanogens direct affects methane content in the AD [35].

\section{Conclusions}

Our experimental results indicate that the mixed inoculum $(\mathrm{SS}+\mathrm{CD}+\mathrm{IOM})$ used in reactor $\mathrm{R} 4$ shows maximum biogas production with the highest methane content. In a mixed inoculum diverse anaerobic (Clostridium and Bacillus spp) and methanogenic (methanobacterium and Methanosarcinaspp) bacteria were present, which increased the hydrolysis, acidogenic, and methanogenic activity in the reactor, and the efficient digestion of substrate took place.

Results from the present study provide evidence that the presence of certain microbial communities affect the mineralization of organic waste significantly, plus the rate of biogas production. So the presence of an active microbial community affects overall digester performance, and for future studies it is one of the most significant parameters for process control and operation. Therefore, it could be suggested that a mixed bacterial culture improves the rate of biogas production as compared to a single bacterial strain due to diverse metabolic capabilities.

\section{Acknowledgements}

This research work was supported by the Higher Education Commission of Pakistan under a start-up research grant and the indigenous Ph.D. scholarship program.

\section{References}

1. KOTHARI R., TYAGI V.V., PATHAK A. Waste-to-energy: A way from renewable energy sources to sustainable development. Renew. Sustain. Energy Rev 14 (9), 3164, 2010.

2. HOLM-NIELSEN J.B., AL SEADI T., OLESKOWICZPOPIEL P. The future of anaerobic digestion and biogas utilization, Bioresource Technol. 100 (22), 5478, 2009.

3. OKONKWO E.N., OKEKE J.U., NWABUEZE CHIOMA J. Principal component regression analysis of $\mathrm{CO}_{2}$ emission. Bay Jr of Pure and App Sci , 6 (1), 27, 2013.

4. HAN S.K., SHIN H.S., Bio-hydrogen production by anaerobic fermentation of food waste, Int. J. Hydro Ene, 29, $569,2004$.
5. YANG Y., TADA C., TSUKAHARA K., SAWAYAMA S. Methanogenic community and performance of fixed- and fluidized-bed reactors with reticular polyurethane foam with different pore sizes. Mat Sci and Engr C-Biom and Sup -mole Sys 24 (6-8), 803, 2004.

6. GRAAF D., FENDLER R. Biogas production in Germany. Federal Environment Agency. Dessau-Rosslau, 29, 2010.

7. DEMIREL B., YENIGUN O., ONAY T.T. Anaerobic treatment of dairy wastewaters: a review. Pro Biochem $\mathbf{4 0}$ (8), 2583, 2005.

8. SAGAGI B.S., GARBA B., USMAN N.S., BAYERO N. Studies on biogas production from fruits and vegetable waste. Journal of Pure and Applied Sciences, 2 (1), 115, 2009.

9. PARK N.D., RONALD W., THRING R.W., STEVE S. Comparison of methane production by co-digesting fruit and vegetable waste with first stage and second stage anaerobic digester sludge from a two stage digester. Water Sci and Tech. 65 (7), 1252, 2012.

10. CHEN Y., CHENG J.J., CREAMER K.S. Inhibition of anaerobic digestion process: A review. Biore Technol. 99 (10), 4044, 2008.

11. FORSTER-CARNEIRO T., PEREZ M., ROMERO L.I., SALES D. Dry-thermophilic anaerobic digestion of organic fraction of the municipal solid waste: focusing on the inoculums sources. Biore. Tech, 98 (17), 3195, 2006.

12. IKE M., INOUE D., MIYANO T., LIU T.T., SEI K., SODA S. Microbial population dynamics during startup of a fullscale anaerobic digester treating industrial food waste in Kyoto eco-energy project. Biore . Technol. 101 (11), 3952, 2010.

13. FRICKE K., SANTEN H., WALLMANN R., HUTTNER A., DICHTL N. Operating problems in anaerobic digestion plants resulting from nitrogen in MSW. Waste Manag. 27 (1), 30, 2007.

14. FANTOZZI F., COSTARELLI I., BURATTI C. Laboratory scale anaerobic digestion at the Italian Biomass Research Centre. In: Fourteenth European BiomassConference and Exhibition, Biomass for Energy, Industry and ClimateProtection, Pari. 2005.

15. LEE M., HIDAKA T., HAGIWARA W., TSUNO H. Comparative performance and microbial diversity of hyperthermophiclic and thermophilic co-digestion of kitchen garbage and excess sludge. Biore Technol. 100 (2), 578, 2009.

16. KIM J.K., CHUN Y.N., KIM S.W. Effects of temperature and hydraulic retention time on anaerobic digestion of food waste. J. Biosci; 102 (4), 328, 2006.

17. NEVES L.C., CONVERTI A., PENNA T. "Biogas production: New trends for alternative energy sources in rural and urban zones," Chemi Engr and Tech 32 (8), 1147, 2009.

18. BOUALLAGUI H., TOUHAMI Y., CHEIKH R.B., HAMDI $\mathrm{M}$. Bioreactor performance in anaerobic digestion of fruit and vegetable wastes. Pro Biochem, 40 (3-4), 989, 2005.

19. ALVAREZ R., LIDEN G. Semi-continuous co-digestion of solid slaughterhouse waste, manure, and fruit and vegetable waste. Renew Ener 33 (4), 726, 2008.

20. EL-MASHAD H.M., ZHANG R. Biogas production from co-digestion of dairy manure and food waste. Bioresour Technol. 101 (11), 4021, 2010.

21. AMJAD S.S., BILAL Q., NAZIR S., HUSSAIN A.Biogas, renewable energy resource for Pakistan. Renew and Susta. Enr Rev, 15 (6) 2833, 2011.

22. SHEIKH M.A. Renewable energy resource potential in Pakistan. Renew and Susta. Enr Rev, 13 (9), 2696, 2009. 
23. American Public Health Association, American Water Works Association, and Water Environment Federation Standard methods for the examination of water and wastewater. $21^{\text {st }}$ ed., American Public Health Association, Washington, D.C, USA. 2005.

24. ZHANG R., EL-MASHAD H.M., HARTMAN K., WANG F., LIU G., CHOATE C., GAMBLE P. Characterization of food waste as feedstock for anaerobic digestion. Bioresour. Technol (4), 929, 2006.

25. WILSON K. Preparation of Genomic DNA from Bacteria» in Current Protocols in Molecular Biology 2.4.1-2.4.5, Supplement 27 (Eds. F.M. Ausubel et al; Wiley InterScience) 1997.

26. BAGI Z., ACS N., BALINT B., HOVRATH L., DOBO K., PEREI K.R., RAKHELY G., KOVACS K.L. Biotechnological intensification of biogas production. Appl Micro \& Biot. 76 (2), 473, 2007.

27. SHARDA DHADSE, KANKAL N.C., BHARTI KUMARI Study of diverse methanogenic and non methanogenic bacteria used for the enhancement of biogas production. Intl Jrnl of Life Sci Biot \& Pharm Res 1 (2), 176, 2012.

28. GOPINATH L.R., MERLIN CHRISTY P., MAHESH K., BHUVANESWARI R., DIVYA D. Identification and Evaluation of Effective Bacterial Consortia for Efficient Biogas Production. Intl. Jrnl. of Env. Sci., Toxi. \& Food Tech. 8 (3), 80, 2014.

29. BOUALLAGUI H., LAHDHEB H., BEN ROMDAN E., RACHDI B., HAMDI M. Improvement of fruit and vegetable waste anaerobic digestion performance and stability with co-substrates addition. Jrnl of Env Manag. 90 (5), 1844, 2009.

30. GARCIA-PEÑA E.I, PARAMESWARAN P., KANG D.W., CANUL-CHAN M., KRAJMALNIK-BROWN R. Anaerobic digestion and co-digestion processes of vegetable and fruit residues: Process and microbial ecology.Bioresour. Technol 102 (20), 9447, 2011.

31. SHIN S.G., LEE S., LEE C., HWANG K., HWANG S. Qualitative and quantitative assessment of microbial community in batch anaerobic digestion of secondary sludge. Bioresour. Technol. 101 (24), 9461, 2010.

32. FRICKE K., SANTEN H., WALLMANN R., HUTTNER A., DICHTL N. Operating problems in anaerobic digestion plants resulting from nitrogen in MSW. Waste Manage. 27 (1), 30-43, 2007.

33. LEE J., SONG J., HWANG S. Effects of acid pre-treatment on bio hydrogen production and microbial communities during dark fermentation. Bioresour. Technol. 100 (3), 1491, 2009.

34. IKE M., INOUE D., MIYANO T., LIU T.T., SEI K., SODA S., KADOSHIN S. Microbial population dynamics during startup of a full-scale anaerobic digester treating industrial food waste in Kyoto eco-energy project. Bioresour. Technol. 101 (11), 3952, 2010.

35. TRZCINSKI A.P., RAY M.J., STUCKEY D.C. Performance of a three-stage membrane bioprocess treating the organic fraction of municipal solid waste and evolution of its archaeal and bacterial ecology. Bioresour. Technol. 101 (6), $1652,2010$. 